\title{
THE IMPACT OF COGNITIVE TRUST AND E-WOM ON PURCHASE INTENTION IN C2C E-COMMERCE SITE
}

\author{
Ika Alfina, Joni Ero, Achmad Nizar Hidayanto and Muhammad Rifki Shihab \\ Faculty of Computer Science, University as Indonesia, Depok, Indonesia
}

Received 2014-08-18; Revised 2014-08-19; Accepted 2014-10-29

\begin{abstract}
In the last few years, the number of Internet users in Indonesia was growing rapidly as many people started to use e-commerce sites. Utilization of $\mathrm{C} 2 \mathrm{C}$ e-commerce in particular has a risk that may reduce people interest in online shopping. Of the many factors that may influence online shopping intention, trust becomes the key. This study built a model to explain the purchase intention in the $\mathrm{C} 2 \mathrm{C} \mathrm{e}$-commerce environment. In the model, buyer's trust to the seller is a major factor that influences the purchase intention. Cognitive trust and adoption of e-WOM information is used as a factor that explains how trust is formed. We tested the model by distributing online questionnaires in Kaskus forum, the largest online shopping community in Indonesia. Total 114 valid questionnaire responses were used for analysis. The analysis was conducted using PLS and Smart PLS 2.0 as the tools. Our results showed that trust have a positive and significant effect to the purchase intention. Later it was found that two cognitive trust variables, the perception of ability and integrity of the seller, along with the adoption of e-WOM information have a positive and significant impact on the trust to the seller.
\end{abstract}

Keywords: C2C, e-WOM, Purchase Intention, Cognitive Trust, Information Adoption

\section{INTRODUCTION}

In recent years, the growing number of Internet users in Indonesia is increasing. Based on MarkPlus Insight survey, the number of Internet users in Indonesia in 2012 reached 61 million people. The amount is $10 \%$ greater than the number of users in the year 2011 and $48 \%$ greater than the number of users in the year 2010. Thus the Internet penetration has reached $23.5 \%$ of the total population in Indonesia. Internet has been used for many purposes, from entertainment such as the use of facebook to personal and company business (Hidayanto et al., 2013; Hidayanto et al., 2014). The study also found that 3.7 million people (6\% of Internet users) perform ecommerce transactions.
E-commerce is a concept that describes the transaction between two parties, the exchange of goods, services, or information, with the Internet as the main medium in the transaction processing (Rainer and Turban, 2002). Although it has advantages over traditional commerce, there are some problems in e-commerce as its online environment nature, such as the difficulty to recognize the identity of the other party and to verify the suitability of the goods offered.

Rofiq (2007) in his study stated that from research conducted by (Pavlou and Gefen, 2002; Corbit et al. 2003; Kim and Tadisina, 2003: Mukherjee and Nath 2003), concluded that of the many factors that can affect the transactions through e-commerce, trust becomes a key factor. Kim et al. (2008) in his study also found that trust becomes an important factor in determining the Corresponding Auhtor: Achmad Nizar Hidayanto, Faculty of Computer Science University as Indonesia, Depok, Indonesia 
intention to buy, so it can be said that considering the presence of risk factors in online shopping, only customers who have a sense of trust that would be willing to conduct transactions over the Internet.

In Indonesia, kaskus.co.id-an online forum, is considered as the most successful Customer-to-Customer (C2C) e-commerce. The exchange of information through the testimony in kaskus forum, can be regarded as a form of electronic Word Of Mouth (e-WOM). According to Cheung and Thadani (2012), many of WOM communication considered as a factor influencing consumer behavior. According to Utz et al. (2012), online buying is usually a situation where there is information asymmetry. Buyers or sellers often have a lack of information about the other party (Jones and Leonard, 2008). The existence of testimony helped to overcome the problems of information asymmetry.

This research was conducted with the aimt o create a model of purchase intention in the $\mathrm{C} 2 \mathrm{C}$ ecommerce environment with trust and eWOM as main factors. An understanding of the factors that influence the buying intention in the e-commerce site will be useful for sellers and providers of e-commerce site to meet their goals.

\section{RESEARCH CONCEPTUAL MODEL}

Based on belief-attitude-intention framework of the Theory Reasoned Action (TRA), Zhang et al. (2010) proposed a trust model that puts cognitive trust as beliefs and emotional trust as attitude. In the model, emotional trust can affect purchase intention and emotional trust is influenced by cognitive trust. In the previous studies, factors used to establish trusting attitude is cognitive trust which composed of ability, benevolence and integrity. Based on this evidence, we posit the following hypotheses:

$\mathrm{H} 1$ = Ability of the seller has a positive impact directly on trust of the consumer to the seller

$\mathrm{H} 2=$ Benevolence of the seller has a positive impact directly on trust of the consumer to the seller

$\mathrm{H} 3$ = Integrity of the seller has a positive impact directly on trust of the consumer to the seller

Regarding e-WOM information adoption, (Sussman and Siegal, 2003; Di and Luwen, 2012) showed that information quality and source credibility has a positive impact on information usefulness. In their literature review, Cheung and Thadani (2012) also indicated that the information quality (stimulus) and source credibility (communicator) is a factor that is often used in social communication. Communicator and the stimulus will affect the response of information recipient. When information in e-WOM has a good quality and can meet the needs of the information receiver, the information will be considered useful. When information received, delivered by people who felt more credible, the information will be considered more influential. Therefore, we posit the following hypotheses:

$\mathrm{H} 4$ = Source credibility has a direct positive effect on perceived information usefulness

H5 = Information quality has a direct positive effect on perceived information usefulness

Cheung and Thadani (2012) also found that the usefulness of the information has a positive direct impact on e-WOM adoption, which is also in line with the result of (Sussman and Siegal, 2003; Di and Luwen, 2012). Thus we posit the following hypothesis:

$$
\begin{aligned}
\mathrm{H} 6= & \text { Information usefulness has a direct positive } \\
& \text { effect on e-WOM information adoption }
\end{aligned}
$$

Xiaorong et al. (2011) in their research proved that eWOM may affect consumer confidence. The same was shown by Smith (2002) in his study concluded that trust is a mediating variable that helps realizing the influence of e-WOM to consumer decisions. From these studies, we conclud that e-WOM can affect a person's attitude, especially the attitude of trust, which then will influence the consumer's decision to buy. Therefore we state the following hypotheses:
$\mathrm{H} 7$ = e-WOM adoption has a positive direct effect on trust
H8 = Trust of the consumer to the seller has a positive impact directly to purchase intention

Figure 1 show our proposed research model tested in this research.

\section{MATERIALS AND METHODS}

This study was conducted on Indonesia's Internet users who visited Kaskus site. This study was conducted over a period of four months, from September 2013 to December 2013. We select Kaskus as our research object considering its highest traffic in Indonesia, based on the rank in alexa.com. In addition, the Kaskus forum has a trading forum therein, which is one of the $\mathrm{C} 2 \mathrm{C}$ marketplace most widely used in Indonesia.

The data in this study was collected using an online questionnaire distributed in Kaskus forum. 


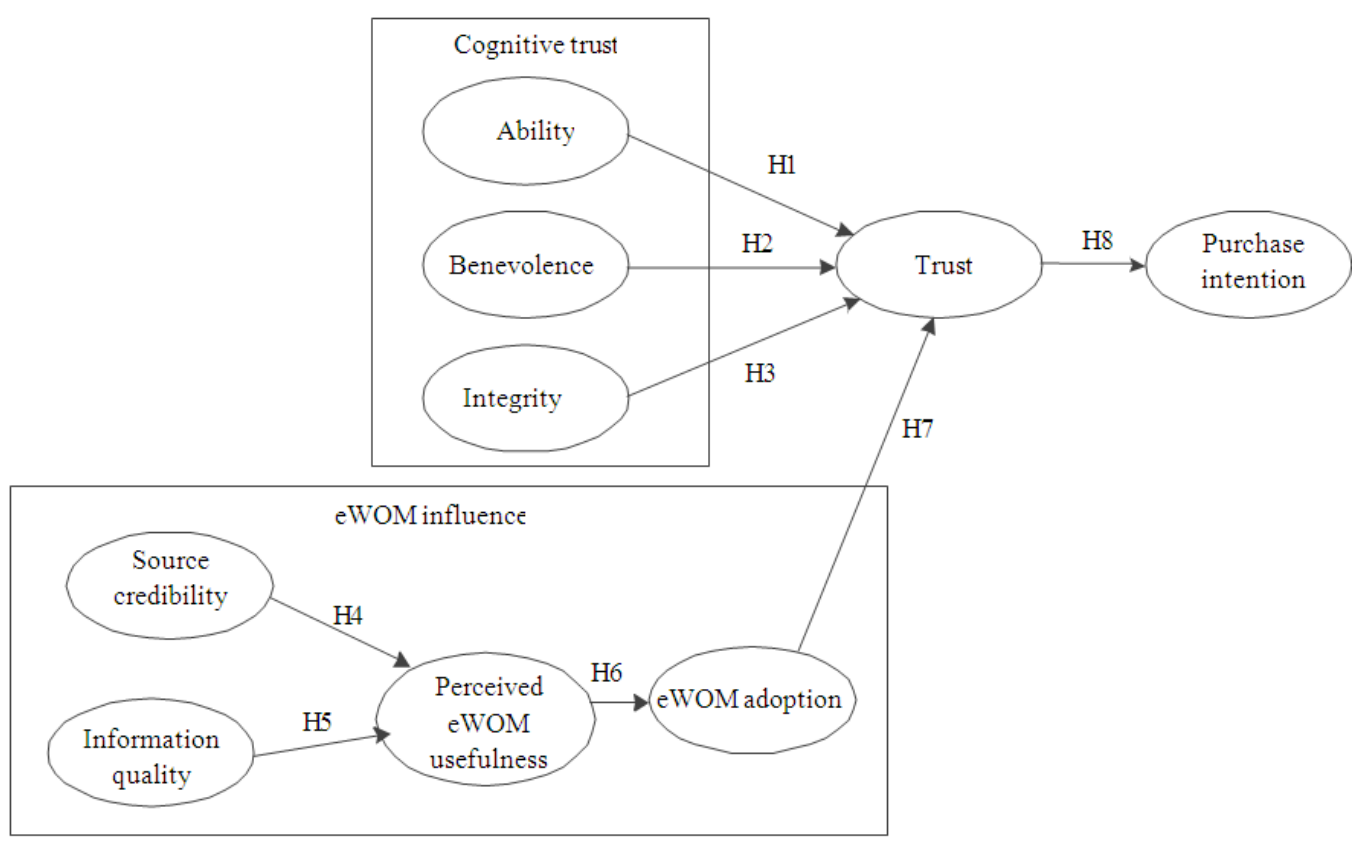

Fig. 1. Research conceptual model

The statements in the questionnaire constructed by using five-points Likert scale, where 5 indicates strongly agree and 1 indicates strongly disagree. Table 1 shows the instrument used in this research.

Before completing the questionnaire, respondents were asked in advance for accessing an online forum thread at Kaskus, where there are sellers who offer products LG G2 smart phone. Respondents (which are considered as a potential buyer) can see the bid details, testimonials from other buyers, sellers' profile and the profile of buyers giving testimony. Facilities within the site were limited, so that the respondent can focus on objects that may affect the studied variables, namely bid displayed by seller, buyer testimonials and the profile of the buyer and seller.

\section{RESULTS}

Of data collection has been done, we obtained 180 respondents. Of the 180 questionnaires, only 114 questionnaires were considered valid, by excluding all respondents who have never shopped online before. Respondents generally dominated by men, with ages between 18-29 years and the education level equivalent to diploma/bachelor degree.

Data was processed using Partial Least Square (PLS) with Smart PLS 2.0 tool. Convergent validity test results showed some indicators (ABI1, PI2, BEN2) do not meet the minimum threshold. After deleting these three items, the
AVE and communality values have met the criteria, which are above 0.5 . From the results of the PLS calculation, shown in Table 2, obtained that except benevolence construct, the values of composite reliability of other latent variables were above 0.7. Hair et al. (2008) in Jogiyanto (2011) stated that the rule of thumb or composite reliability alpha value must be greater than 0.7 , even if the value of 0.6 is acceptable. As the composite reliability value of benevolence construct is 0.6721 , we can say that the benevolence construct is also reliable. Therefore, we conclude that our measurement model is reliable.

Structural model test results showed the value of $\mathrm{R}^{2}$ for each endogenous latent variable. Purchase intention variable has a value of $\mathrm{R}^{2} 0.4198$ which indicates that as many as $41.98 \%$ variance of purchase intention can be explained by the trust and the trust variable has a value of $\mathrm{R}^{2} 0.5525$ which indicates that as many as $55.25 \%$ of variance of trust can be explained by ability, benevolence, integrity and e-WOM information adoption. According to Chin (1998), these $\mathrm{R}^{2}$ values can be classified as moderate, as the values are between 0.33 and 0.67 . Information adoption has $\mathrm{R}^{2}$ of 0.212 and perceive information usefulness has a $\mathrm{R}^{2}$ of 0.1621 .

In addition, the test results of the discriminant validity showed that there was no correlation between latent variables value greater than the value of the square root AVE of the latent variable itself, so it can be concluded that the measurement model can be said to be valid. 
To test the hypotheses that have been defined, the value of Original sample (O) and t-statistics should be compared. According to Haas and Lehner (2009), path coefficient values in the range of -0.1 to 0.1 are considered insignificant, values above 0.1 is significant and directly proportional, while a value below -0.1 is worth significantly but inversely correlated. According to Ghozali (2011), the value of t-statistics is considered significant if it is above 1.96. Thus as can be seen in Table 3, H2 and $\mathrm{H} 4$ are rejected while other hypotheses are accepted.

Table 1. Research instrument

\begin{tabular}{|c|c|c|}
\hline Code & Indicator & References \\
\hline \multicolumn{3}{|c|}{ Ability (ABI) } \\
\hline ABI1 & Competency & Zhang et al., 2010 \\
\hline $\mathrm{ABI} 2$ & Experience & Zhang et al., 2010 \\
\hline $\mathrm{ABI} 3$ & Knowledge & Zhang et al., 2010 \\
\hline $\mathrm{ABI} 4$ & Expertise & McKnight et al., 2002 \\
\hline \multicolumn{3}{|c|}{ Benevolence (BEN) } \\
\hline BEN1 & Attention & Zhang et al., 2010 \\
\hline BEN2 & Willingness to help & Zhang et al., 2010 \\
\hline BEN3 & Not only thinking of his own advantage & McKnight et al., 2002 \\
\hline \multicolumn{3}{|c|}{ Integrity (INT) } \\
\hline INT1 & Frankly & Zhang et al., 2010 \\
\hline INT2 & Honestly & McKnight et al., 2002 \\
\hline INT3 & Committed & Zhang et al., 2010 \\
\hline \multicolumn{3}{|c|}{ Trust (TRU) } \\
\hline TRU1 & Feeling believe & Zhang et al., 2010 \\
\hline TRU2 & Feeling believe is the right decision & Zhang et al., 2010 \\
\hline TRU3 & Feeling comfortable & Komiak and Benbasat, 2006 \\
\hline TRU4 & Feeling satisfied & Komiak and Benbasat, 2006 \\
\hline \multicolumn{3}{|c|}{ Purchase Intention (PI) } \\
\hline PI1 & It is possible to buy & Zhang et al., 2010 \\
\hline PI2 & Considering buying & Zhang et al., 2010 \\
\hline PI3 & Would seriously consider buying & Zhang et al., 2010 \\
\hline PI4 & Allows to recommend & Jarvenpaa et al., 2000 \\
\hline \multicolumn{3}{|c|}{ Source Credibility (SC) } \\
\hline $\mathrm{SC} 1$ & Trustworthiness & Bhattacherjee and Sanford, 2006 \\
\hline $\mathrm{SC} 2$ & Have credibility & Bhattacherjee and Sanford, 2006 \\
\hline $\mathrm{SC} 3$ & Reliable & Bhattacherjee and Sanford, 2006 \\
\hline \multicolumn{3}{|c|}{ Information Quality (IQ) } \\
\hline IQ1 & Relevant & Kim et al., 2008 \\
\hline IQ2 & Accurate & Kim et al., 2008 \\
\hline IQ3 & Clear and complete & Kim et al., 2008 \\
\hline \multicolumn{3}{|c|}{ Perceived Information Usefulness (PIU) } \\
\hline PU1 & Useful & Kim et al., 2008 \\
\hline PU2 & Helping & Kim et al., 2008 \\
\hline PU3 & Facilitate the work & Kim et al., 2008 \\
\hline \multicolumn{3}{|c|}{ E-WOM Information Adoption (EIA) } \\
\hline ADOP1 & Motivating & Sussman and Siegal, 2003 \\
\hline ADOP2 & Following information & Sussman and Siegal, 2003 \\
\hline ADOP3 & Agree with information & Sussman and Siegal, 2003 \\
\hline
\end{tabular}


Ika Alfina et al. / Journal of Computer Science 10 (12): 2518.2524, 2014

Table 2. Summary of PLS calculation results after deletion

\begin{tabular}{lcllr}
\hline Construct & AVE & Composite reliability & Cronbachs alpha & R square \\
\hline ABI & 0.5106 & 0.7578 & 0.7895 & 0.0000 \\
EIA & 0.6469 & 0.8459 & 0.8276 & 0.2120 \\
BEN & 0.5066 & 0.6721 & 0.5244 & 0.0000 \\
INT & 0.5812 & 0.8041 & 0.8247 & 0.0000 \\
IQ & 0.7245 & 0.8875 & 0.8542 & 0.0000 \\
PI & 0.5357 & 0.7730 & 0.7016 & 0.4198 \\
PIU & 0.6228 & 0.8305 & 0.8404 & 0.1621 \\
SC & 0.6721 & 0.8590 & 0.8533 & 0.0000 \\
TRU & 0.5217 & 0.8130 & 0.8587 & 0.5525 \\
\hline
\end{tabular}

Table 3. Hypotheses testing result

\begin{tabular}{lllllll}
\hline Hypothesis & $\mathrm{O}$ & $\mathrm{M}$ & STDEV & STERR & $\mid$ O/STERR| & Conclusion \\
\hline ABI $\rightarrow$ TRU & 0.1839 & 0.1882 & 0.0834 & 0.0834 & 2.2036 & H1 is accepted \\
BEN $\rightarrow$ TRU & 0.0223 & 0.0714 & 0.0548 & 0.0548 & 0.4066 & H2 is rejected \\
INT $\rightarrow$ TRU & 0.2352 & 0.2325 & 0.0895 & 0.0895 & 2.6263 & H3 is accepted \\
SC $\rightarrow$ PIU & 0.1743 & 0.1866 & 0.1134 & 0.1134 & 1.5374 & H4 is rejected \\
IQ $\rightarrow$ PIU & 0.2533 & 0.2619 & 0.123 & 0.123 & 2.0596 & H5 is accepted \\
PIU $\rightarrow$ EIA & 0.4605 & 0.4713 & 0.0957 & 0.0957 & 4.8104 & H6 is accepted \\
EIA $\rightarrow$ TRU & 0.4818 & 0.4767 & 0.0812 & 0.0812 & 5.9303 & H7 is accepted \\
TRU $\rightarrow$ PI & 0.6479 & 0.6535 & 0.0657 & 0.0657 & 9.8564 & H8 is accepted \\
\hline
\end{tabular}

\section{DISCUSSION}

Based on the results of hypothesis testing, in accordance to the relationship between cognitive trust and trust, ability and integrity have a positive and significant impact on the feeling of trust to the seller, while benevolence does not affect trust to the seller. Because of insignificant impact of benevolence to trust, the findings in this study are different from the results of Zhang et al. (2010) who showed that three trusts cognitive factors, namely ability, benevolence and integrity have a significant impact on trust to the seller. Different results were also shown in the study of Rofiq (2007), which also studied e-commerce users in Indonesia, where the findings showed the only factor that affects trust is the integrity.

The findings in this study means that the factors that influence users' trust to $\mathrm{C} 2 \mathrm{C}$ site in Indonesia is ability and integrity. In order to have a sense of trust to the seller, the buyers expects $\mathrm{C} 2 \mathrm{C}$ site to demonstrate its ability to meet the needs of buyers and demonstrate integrity while maintaining a commitment and honesty.

Based on the results of hypothesis testing, in accordance to relationship between e-WOM information adoption to trust, it shows that the adoption of e-WOM infromation has a significant positive effect on trust to the seller. From the value of coefficient of determination, it also can be seen that the combination of cognitive trusts: Ability, benevolence and integrity, as well as the adoption of the
e-WOM information can explain $55.25 \%$ of variance of the trust. It showed that e-WOM is an important component to establish trust from buyer to the seller.

In this study, the adoption of e-WOM information shown to be affected by the perceived information usefulness with the coefficient of determination worth $21.2 \%$, which means this variable has weak explanatory power against information adoption. The results of this study are consistent with the results of the research of Di and Luwen (2012) who also showed that the perception of the usefulness of the information has a positive influence to the adoption of information.

Based on the hypothesis test results showed that the quality of information has a significant positive effect on the perceived information usefulness of eWOM, while the information source credibility is proved not significantly affect the perceived e-WOM information usefulness. These findings differ from studies of Di and Luwen (2012) which shows the source credibility has positive and significant effect on information usefulness. The insignificant result for the information source credibility factor in this study may be caused by conditions at the Kaskus site where the testimonies interface displays only the name of the user who gave testimony without directly showing attributes that can help determine the credibility of the testimonial giver, so most of the respondents who are Kaskus' users have their own perception on the usefulness of testimony. 
Our hypothesis testing also showed that trust has a significant effect on intention to purchase. From the coefficient of determination, it can be seen that $41.98 \%$ variance of purchase intention can be explained by the trust. This result is inline with the results of (Kim et al., 2008; Zhang et al., 2010; Lee et al., 2011; Hidayanto et al., 2012).

\section{CONCLUSION}

The results of the study are able to reveal consumer behavior in Indonesia in shopping online, especially related trust factor and e-WOM. Our analysis results showed that trust is influenced by the ability and integrity of the seller as well as e-WOM. Trust to the seller in this study proved to be a decisive factor for the consumer interest in online shopping. This has implications for the seller to increase the importance of trust to consumers to show its sincerity in fulfilling all of the services that have been promised. Sellers on ecommerce environment are also expected to pay attention to e-WOM by giving consumers a chance to write positive experience when shopping with the seller.

\section{ACKNOWLEDGEMENT}

This research is fully supported by Universitas Indonesia through 'Hibah Riset UI 2013-PUPT (BOPTN)' No. 2706/H2.R12/HKP.05.00/2013. It is a pleasure to convey our gratitude to our university for their continuous support, particularly for Research and Community Engagement Directorate for their excellent services.

\subsection{Author's Contributions}

All authors equally contributed in this work.

\subsection{Ethics}

This article is original and contains unpublished material. The corresponding author confirms that all of the other authors have read and approved the manuscript and no ethical issues involved.

\section{REFERENCES}

Bhattacherjee, A. and C. Sanford, 2006. Influence processes for information technology acceptance: An elaboration likelihood model. MIS Quarterly, 30: $805-825$.
Cheung, C.M.K. and D.R. Thadani, 2012. The impact of electronic word-of-mouth communication: A literature analysis and integrative model. Decision Support Syst., 54: 461-470. DOI: 10.1016/j.dss.2012.06.008

Chin, W.W., 1998. The Partial Least Squares Approach for Structural Equation Modeling. In: Modern Methods for Business Research, Marcoulides, G.A. (Ed.)., Erlbaum, Mahwah, pp: 295-358.

Corbit, B.J., T. Thanasankit and H. Yi, 2003. Trust and e-commerce: A study of consumer perceptions. Elect. Comm. Res. Applic., 2: 203-215. DOI: 10.1016/S1567-4223(03)00024-3

Di, C. and W. Luwen, 2012. Factors affecting e-WOM adoption. Unpublished bachelor thesis, Hong Kong: Hong Kong Baptist University.

Ghozali, I., 2011. Structural equation modeling metode alternatif dengan Partial Least Square (PLS). Edisi 3. Semarang, Badan Penerbit-Undip.

Haas, N. and F. Lehner, 2009. Knowledge management success factors-proposal of an empirical research. Elect. J. Knowledge Manag., 8: 79-90.

Hair, J.F.J., J.S. Bolesa and M.W. Johnstonb, 2008. Role stress, work-family conflict and emotional exhaustion: Inter-relationships and effects on some work-related consequences. J. Personal Sell. Sales Manag. 17: 17-28. DOI: 10.1080/08853134.1997.10754079

Hidayanto, A.N., H. Saifulhaq and P.W. Handayani, 2012. Do Consumers Really Care on Risks in Online Shopping? An Analysis from Indonesian Online Consumers. In proceedings of IEEE 6th International Conference on Management of Innovation and Technology, Bali.

Hidayanto, A.N., W.M. Mukhodim, Frisca and K.M. Junus, 2013. Analysis of Service Quality and Important Features of Property Websites in Indonesia. Pacific Asia J. of the Assoc. of Inform. Syst., 5: Article 2.

Hidayanto, A.N., I.N. Razaad, M.R. Shihab and Z.A. Hasibuan, 2014. Corporate blog usage and its success factors: multiple case studies at consulting firms in Indonesia. Int. J. Innov. and Learn., 16: 253-276. DOI: 10.1504/IJIL.2014.064729

Jarvenpaa, S.L., N. Tractinsky and M. Vitale, 2000. Consumer trust in an Internet store. Inform. Technol. Manag., 1: 45-71. DOI: 10.1023/A:1019104520776 
Jogiyanto, 2011. Structural Equation Modeling Berbasis Varian dalam Penelitian Bisnis. Yogyakarta, Unit Penerbit dan Percetakan STIM YKPN.

Jones, K. and L.N.K. Leonard, 2008. Trust in consumerto-consumer electronic commerce. Inform. Manag., 45: 88-95. DOI: 10.1016/j.im.2007.12.002

Kim, D., D. Ferrin and H. Rao, 2008. A trust-based consumer decision-making model in electronic commerce: The role of trust, perceived risk and their antecedents. Dec. Supp. Syst., 44: 544-564. DOI: 10.1016/j.dss.2007.07.001

Kim, E. and S. Tadisina, 2003. Customer's initial trust in e-business: How to measure customer's initial trust. Proceedings of the 9th Americas Conference on Information Systems, Aug. 4-6, AMCIS, Tampa, FL, USA, pp: 35-41.

Komiak, S.Y.X. and I. Benbasat, 2006. The effects of personalizaion and familiarity on trust and adoption of recommendation agents. MIS Quarterly, 30: 941-960.

Lee, M.K.O., N. Shi, C.M.K. Cheung, K.H. Lim and C.L. Sia, 2011. Consumer's decision to shop online: The moderating role of positive informational social influence. Inform. Manag., 48: 185-191. DOI: 10.1016/j.im.2010.08.005

McKnight, D.H., V. Choudhury and C. Kacmar, 2002. The impact of initial consumer trust on intentions to transact with a web site: A trust building model. J. Strat. Inform. Syst., 11: 297-323. DOI: 10.1016/S0963-8687(02)00020-3

Mukherjee, A. and P. Nath, 2003. A model of trust in online relationship banking. Int. J. Bank Market., 2: 5-15. DOI: 10.1108/02652320310457767

Pavlou, P.A. and D. Gefen, 2002. Building effective online marketplaces with institution-based trust. Proceedings of 23rd International Conference on Information Systems, (CIS' 02), Linthicum, Maryland, USA, pp: 667-675. DOI: 10.1287/isre.1040.0015
Rainer, R.K. and E. Turban, 2002. Introduction to information technology. Canada: John Wiley Sons.

Rofiq, A., 2007. Pengaruh dimensi kepercayaan trust terhadap partisipasi pelanggan e commerce. Malang: Universitas Brawijaya Malang, Indonesia.

Smith, D.N., 2002. Trust Me, Would I Steer You Wrong? The Influence of Peer Recommendations Within Virtual Communities. 1st Edn., University of Illinois at Chicago, pp: 222.

Sussman, S.W. and W.S. Siegal, 2003. Informational influence in organizations: An integrated approach to knowledge adoption. Inform. Syst. Res., 14: 4765. DOI: $10.1287 /$ isre.14.1.47.14767

Utz, S., P. Kerkhof and J.V.D. Bos, 2012. Consumers rule: How consumer reviews influence perceived trustworthiness of online stores. Elect. Comm. Res. Applic., 11: 49-58. DOI: 10.1016/j.elerap.2011.07.010

Xiaorong, F., Z. Bin, X. Qinghong, X. Dan Liuli and C. $\mathrm{Yu}, 2011$. Impact of quantity and timeliness of ewom information on consumer's online purchase intention under C2C. Asian J. Bus. Res., 37-52.

Zhang, K.Z.K., M.K.O. Lee, C.M.K. Cheung, A.X.L. Shen and X.L. Jin et al., 2010. Exploring the moderating effect of information inconsistency in a trust-based online shopping model. Proceedings of the 43rd Hawaii International Conference on System Sciences, Jan. 5-8, IEEE Xplore Press, Honolulu, HI, pp: 1-9. DOI: 10.1109/HICSS.2010.202 